\title{
The Degree of Including International Standards of Science Education in the Physics Syllabus of Palestinian Secondary Schools
}

\author{
Inas Aref Saleh Naser ${ }^{1, *}$ \\ ${ }^{1}$ Curriculum and Instruction Department, AL-Quds University, Alquds-Abudees, Palestine \\ *Correspondence: Curriculum and Instruction Department, AL-Quds University, Alquds-Abudees, Palestine. E-mail: \\ inaser@staff.alquds.edu
}

Received: November 19, 2017

Accepted: December 11, 2017 Online Published: May 22, 2018

doi:10.5430/wje.v8n3p18

URL: https://doi.org/10.5430/wje.v8n3p18

\begin{abstract}
This study aimed at finding out the degree of including international standards of science education in the physics syllabus of the secondary stage in Palestinian schools. The sample of the study consisted of the analytical aspect of the physics textbooks of the eleventh and twelfth grades. The findings of the study show that the rates of including international standards of science education in these textbooks do not match expectations. The study also shows that the criterion of physics ranked first on the study scale among the criteria of content, followed by the criterion of science as a survey, and then the criterion of unified concepts and processes of science. However, there is obvious omission of the standards of science and technology, science from personal and societal perspectives, and the history and nature of science. In light of these results, the researcher recommends the development of the physics syllabus of the secondary stage to include international standards. The study, further, calls for more research on the assessment of physics textbooks and other disciples of science at different educational levels in view of content standards as well ason the impact of including such standards on the learning outputs.
\end{abstract}

Keywords: scientific education, international standards of science education, content standards

\section{Introduction}

These days, teaching science witnesses, both locally and internationally, great interest and continuous development due to the challenges presented by the enormous developments in scientific literacy and the scientific and technological achievements of the twenty first century(Chiaepetta, Fillman and Sethna, 1993). Science education has experienced the rise of several development projectswhich aim at achieving science literacy for all students. Among these is the 2061 project which was introduced by the American Association for Advancement of Science (AAAS) in 1989. This project aimed at reinforcing the scientific literacy of the Americans, with special focus on the need for facing any potential challenges and obstacles that might hinder the achievement of this objective. In this context, it is worth mentioning that the interrelation between science, mathematics, and technology is the core means of science education towards scientific literacy (AAAS, 1989).

The interest in achieving scientific literacy is not confined to the 2061 project. Many modern projects on developing the teaching of science have adopted the same idea, mainly the project of International Science Education Standards which was developed by the US National Research Council (NRC) in 1995. NESES emphasize the idea of science literacy in a way that corresponds to the description used by the 2061 project, a matter which establishes a unique framework that is different from old frameworks which were overloaded with the scientific content and focused mainly on covering as much of the content (Goodrum, Hackling and Rennie, 2001).

The standards in question include six major fields (NRC, 1994, 1995, 1996; Hampton \&Lincona; Trowbridge, 2000). These are standards of science content, standards of teaching science, standards of job development, assessment criteria, standards of science education, and standards of system). The focus in the present study was on science content standards.

Science content standards explain what students should know and what to be able to do and perform in natural sciences. Therefore, these standards are concerned with an integratedset of outputs which do not describe the nature of content, but rather are helpful in achieving the main objective represented in teaching the requirements of science 
literacy. These standards fall into eight fields, which are: science as a means for survey, physics, biology, earth and space sciences, science from personal and societal perspectives, history and nature of science, and unified concepts and process of science.

It is common sense that teaching physics has many functional objectives, as upgrading students' level of understanding of physics concepts, teaching students the ability to improve their understanding of natural phenomena, improving critical thinking, increasing the affectivity of learning, improving science appreciation and assessment, and finally acquiring the skills needed for scientific processes in a functional way (Cavallo, Rozman\& Potter, 2004). There have been continuous efforts seeking to improve the physics curricula in many countries around the world. Such efforts have influenced the physics curricula of the Arab countries, including Palestine. Consequently, several adaptations and changes have been introduced to make these curricula more acceptable by both learners and teachers (Badran, 1991)

A considerable number of studies have been carried out to investigate the degree of including international standards of science education in science curricula. Chaippetta, filman and Sethna, (1991) conducted an analytical study on secondary stage chemistry textbooks and the teaching aids employed by the curricula. The results of their study showed that the content of six of the investigated textbooks focused on the component of science as part of scientific knowledge. The study also found out that the seven textbooks investigated by the researchers did not stress the component of science as an approach for thinking, and that the content was excessive in terms of the number of pages. In his study, Haury (2000) analyzed biology textbooks in the U.S. to investigate how much they agree with the objectivesof science education enlisted by international standards of science education. The results showed that there was obvious disregard of vital science concepts. The focus of the curriculum was on technical terms and on minor measurable details. The study, further, pointed out that American students were receiving modest assistance in discussing the results of the learning activities pertaining toscience concepts.

Westerlund and West (2000), carried out a brief study to assess a selected biology test (ECO) at Texas high schools based on international standards of science education. The researchers used an instrument to measurescience literacy through comparing test questions against international standards of assessment. The study found out that the test applied did not meet the criteria of science education relevant to biology concepts. Besides, there was deficiency in assessing three of the standards of the content of science education.

In the Palestinian context, Al-Khaledi (2004) did an analytical study on the newly adopted Palestinian syllabus to investigate its ability for training and qualifying individuals who enjoy adequate and balanced science literacy. The study found out that the Palestinian science syllabus lacks the desired balance and focuses only on part of the science literacy aspects. Still, the calculated percentages of literacy science mismatch the recommendations of experts.

In a study conducted on Jordanian students, Safi (2005) investigated the impact of teaching on the level of science literacy and achievement of students taking a content of physics that was designed in light of international standards. The study showed a positive impact of teaching such content on the students' level of science literacy and achievement.

Al-Lu'lu' (2007) did a study which aimed at finding out the quality of the physics subjects covered by the Palestinian science syllabus of the primary stage with reference to international standards of science syllabus. The results showed that the percentages of such standards are $33 \%$ for the first grade syllabus, $87 \%$ for the second, $46 \%$ for the third, and $100 \%$ for the fourth grade syllabus. Moreover, the new Palestinian syllabus includes additional subjects, which adds to the information presented, although such subjects neither follow a systematic order nor do they treat the material concept as a basic physical one.

In a Jordanian study, Cannan (2005) investigated the range of correspondence between science education in the fifth, sixth, seventh and eighth grades and international standards. The study also aimed at determining the impact of a standardized unit of study on the students' achievement in science concepts. The outcomes showed that the rate of correspondence was $39 \%$.

In another Jordanian study, Al-Atrash (200) examined the degree of including international standards of content in the science syllabus of the primary stage of Jordanian schools as well as the impact of teaching a standardized unit on the students' level of science literacy and their attitudes towards sciences. The findings of the study indicated that the science syllabus included the three traditional standards of science content, namely natural sciences, biology, and earth and space sciences. Further, there was significant omission of the standards of science and technology and those of history and nature of science.

Abu Masmah (2006) analyzed the questions presented by both the physics syllabus of the secondary stage and the 
general secondary exams to find out how much the meet with international standards of science education. The results showed a lack of decision making questions in physics textbooks and in general exams.

Finally, Al-Khitabi and Al-Shu'aili (2007) did a study to find out the degree of following international standards of science syllabus of the fifth grade in Jordan. The results showed that the syllabus highly observed international standards; yet there was poor consideration of the fields of science and technology, science from personal and societal perspectives, history and nature of science, and science concepts and processes.

It becomes clear through all these previous studies that some of them analyzed the syllabi, programs, or exams of science with reference to international standards of science education. The results of all these studies call for more research on analyzing the content of science textbooks adopted at different levels.

\section{Problem of the Study}

The present study mainly aims at finding out the degree of including international standards of science education in the physics syllabus of Palestinian secondary schools.

\section{Significance of the Study}

The significance and importance of the present study come from the fact that it goes side by side with up-to-date world efforts of improving science teaching as well as the need for developing science curricula according to the requirements of the science and technology of today's life. The study is performedamid the efforts of Palestinian Ministry of Education to develop science curricula in the hope to achieve the main objective of instruction, represented in qualifying and preparing science literate individuals. Therefore, the study provides real information and statistics that will hopefully contribute to the improvement of physics curriculum. Besides, the study presents a list of assessment standards that are helpfulin assessing the content of science textbooks, which may ultimately assist researchers in the fields of science education and science instruction. It is hoped that this work of research will benefit those entrusted in introducing and developing science curricula and syllabi.

\section{Community and Sample of the Study}

The community and sample of the study include the textbooks used in teaching physics to eleventh and twelfth graders at Palestinian secondary schools in 2016.

\subsection{Study Procedures}

The following research procedures were carried out throughout this study:

1) Determining the objective behind the analysis. This deals measuring the rate of including international standards of science education in the physics syllabus of Palestinian secondary schools.

2) Selecting the community and sample of the study. These are the physics textbooks adopted in the secondary stage.

3) Determining the categories of analysis which includethe content standards derived from international standards of science education.

4) Analyzing the content of the physics textbooks of the secondary stage by both the present researcher and another one. Analysis was done again using Cooper scale to prove its validity.

5) Applying the appropriate statistical procedures of frequency and percentages to determine the results.

\subsection{Instruments of the Study}

The instrument of content analysis was used in this study, and it was developed according to the following procedure:

The researcher interpreted international standards of science education as they were introduced by the National Academy for Sciences (NRC, 1996). Then, she derived the indicators of standards involved by the instrument of analysis. This instrument involved six fields of science content standards. They were the unified processes and concepts of science, science as a survey, physics, biology, earth and space sciences, science and technology, science from personal and societal perspectives, and history and nature of science. However, the fields of biology and earth and space sciences enlisted under the content standards were excluded from the instrument due to the fact that the applied physics syllabus is separate and lacks other science literacy branches. Further, the list was submitted to an 
expert for translation check.

\subsection{Validity of Content Analysis Instrument}

To prove the capacity of the items of analysis instrument, to represent the domains of standards, and to suggest percentages appropriate to the accepted rate of major standards in physics textbooks, the Arabic version of the instrument was submitted to a committee of seven faculty arbitrators from Universities. Table (1) shows the means calculated by the arbitrators on the suggested rates/percentages.

Table 1. Means Calculated by Arbitrators on the Suggested Rates/Percentages

\begin{tabular}{lc}
\hline \multicolumn{1}{c}{ Standardized Domain } & Mean of Percentage \\
\hline Science unified processes and concepts & $10 \%$ \\
Science as a survey & $20 \%$ \\
Physics & $30 \%$ \\
Science and technology & $15 \%$ \\
Science from personal \& societal perspectives & $15 \%$ \\
History \& nature of science & $10 \%$ \\
Total & $100 \%$ \\
\hline
\end{tabular}

Comparing the percentages presented by previous studies on international standards, as Al-Atrash's, the researcher finds out that they correlate with data presented in table (1).

\subsection{Reliability of Analysis Procedure}

To prove the validity of the analysis procedure, the researcher applied the following two approaches.

-Reliability over the time: The researcher analyzed the physics textbooks of the eleventh and twelfth graders of the scientific stream twice, with a break for two months. The percentages of correlation and agreement in the six domains of content ranged between $85 \%$ and $100 \%$. This indicates that there is an adequate degree of validity over the time which serves the purposes of the study.

-Reliability via individuals: The researcher explained the procedure of analysis with reference to international standards as revealed by a secondary school teacher who has an MSc degree. Four sessions, one hour each, were held with this teacher to analyze a selected unit. It was agreed to distribute the unit's items over the indicators of content standards' domains. Accordingly, one unit of the eleventh grade physics syllabus was selected randomly. The teacher was invited to participate in analyzing the unit. The results of analysis were compared with those arrived at by the researcher herself. The percentages of agreement, presented in table (3), were calculated using Cooper scale. The percentages rated from $92 \%$ to 100\%. This indicates relative agreement and correspondence between the researcher and the school teacher, which was for the benefit of the study purposes.

\subsection{Methodology of the Study}

The researcher applied the analytical descriptive method in analyzing the degree of including international standards.

\subsection{Mechanism of Content Analysis}

The content of the eleventh and twelfth grades' physics syllabus was analyzed according the following steps:

- The content was reading and then divided it into two categories of items. Each item was treated as a unit of analysis, which in turn could be one sentence or more.

-Items were classified, as presented in the appendix, according to their correspondence with sub content standards enlisted under the international standards for science education.

-The frequency of each factor of the six major content standards was calculated after sub standards of content were done.

- Frequency tables were created to show the frequency and percentages of items with reference to the content standards of the syllabus.

- The percentages of each of the content standards included in the physics syllabi of the two grades were compared, as in table one above. 


\section{Results of the Study}

As stated before, the present study aimed at investigating the degree of including international standards of science education in the Palestinian physics syllabus of the secondary stage.

It was found the investigated syllabus included 1124 items which were distributed over the two grades, as shown in table (2) below.

Table 2. Number of Items Distributed over Eleventh and Twelfth Grades

\begin{tabular}{ll}
\hline Grade textbook & Number of items \\
\hline Eleventh grade & 680 \\
Twelfth grade & 444 \\
Total & 1124 \\
\hline
\end{tabular}

Tables (3, 4, 5, 6, 7, 8) below show the results of analyzing the physics syllabus using the instrument designed for the purpose of the study. It also presents the calculated frequencies and percentages of the six indicators of content standards of unified concepts and processes, science as a survey, physics, science and technology, science from personal and societal perspectives, and history and nature of science.

Table 3. Frequencies and Percentages Calculated on the Standard of Unified Concepts and Processes of Science as Shown in Physics Textbooks of the Two Grades

\begin{tabular}{|c|c|c|c|c|c|c|}
\hline \multirow{2}{*}{$\begin{array}{l}\text { Unified concepts and } \\
\text { processes }\end{array}$} & \multirow[t]{2}{*}{ Items of sub standard } & \multicolumn{2}{|c|}{ Physics for $11^{\text {th }}$ grade } & \multicolumn{2}{|c|}{$\begin{array}{l}\text { Physics for } 12^{\text {th }} \\
\text { grade }\end{array}$} & \multirow{2}{*}{$\begin{array}{l}\text { Total } \\
\text { percent }\end{array}$} \\
\hline & & Frequency & Percent & Frequency & Percent & \\
\hline \multirow{3}{*}{$\begin{array}{l}\text { 1-1 System, order and } \\
\text { organization }\end{array}$} & 1-1-1 system & 16 & 8.84 & 4 & 5.26 & 7.05 \\
\hline & 1-1-2 order & 12 & 6.62 & 6 & 7.89 & 7.25 \\
\hline & 1-1-3 organization & 5 & 2.72 & 4 & 5.26 & 4.01 \\
\hline \multirow[t]{2}{*}{ Total } & & 33 & 18.22 & 14 & 18.41 & 18.31 \\
\hline & 1-2-1 evidence & 3 & 1.66 & 2 & 2.63 & 2.14 \\
\hline 2-1 Evidence, model, & 1-2-2 model & 7 & 3.87 & 14 & 18.42 & 11.14 \\
\hline interpretation & 1-2-3 interpretation & 40 & 22.10 & 13 & 17.10 & 19.60 \\
\hline Total & & 50 & 27.63 & 29 & 38.15 & 32.89 \\
\hline 1-3 validity, change, & 1-3-1 validity & 11 & 6.07 & 9 & 11.84 & 8.95 \\
\hline \multirow{2}{*}{ measurement } & 1-3-2 change & 24 & 13.25 & 5 & 6.58 & 9.91 \\
\hline & 1-3-3 measurement & 31 & 17.12 & 7 & 9.12 & 13.16 \\
\hline Total & & 66 & 36.45 & 21 & 27.63 & 32.04 \\
\hline \multirow[t]{2}{*}{ 4-1 progress and balance } & 1-4-1Progress & 00 & 00 & 00 & 00 & 00 \\
\hline & 1-4-2balance & 2 & 1.10 & 4 & 5.26 & 3.18 \\
\hline Total & & 2 & 1.10 & 4 & 5.26 & 3.18 \\
\hline $5-1$ & 1-5-1 form and function & 30 & 16.57 & 8 & 10.52 & 13.54 \\
\hline Total & & 30 & 16.57 & 8 & 10.52 & 13.54 \\
\hline Total of all items & & 181 & 100 & 76 & 100 & 100 \\
\hline
\end{tabular}


Table (3) above shows that the percentages of the sub standards of the physics of the eleventh and twelfth grades are according to the following descending order: $32.89 \%$ for the standards of evidence model, and interpretation; $32.04 \%$ for validity, change and measurement; $18.31 \%$ for system, order, and organization; $13.54 \%$ for form and content; and $3.18 \%$ for progress and balance.

Table 4. Percentages of Sub Standards Calculated on the Standard of Science as a Survey

\begin{tabular}{|c|c|c|c|c|c|c|}
\hline \multirow{2}{*}{ Science as a survey } & \multirow[t]{2}{*}{ elements of sub standard } & \multicolumn{2}{|c|}{ Physics of $11^{\text {th }}$ grade } & \multicolumn{2}{|c|}{ Physics of $12^{\text {th }}$ grade } & \multirow[t]{2}{*}{ Total percent } \\
\hline & & Frequency & Percent. & frequency & percent & \\
\hline \multirow[t]{6}{*}{$\begin{array}{l}\text { 2-1 abilities needed for } \\
\text { scientific survey }\end{array}$} & $\begin{array}{l}\text { 2-1-1 determining questions } \\
\text { \& concepts \& hypotheses }\end{array}$ & 36 & 18.27 & 11 & 10.57 & 14.42 \\
\hline & $\begin{array}{l}\text { 2-1-2 Designing scientific } \\
\text { research }\end{array}$ & 79 & 40.1 & 57 & 54.8 & 47.45 \\
\hline & $\begin{array}{l}2-1-3 \text { using math and } \\
\text { technology to improve } \\
\text { research }\end{array}$ & 11 & 5.58 & 8 & 7.69 & 6.63 \\
\hline & $\begin{array}{l}\text { 2-1-4 formation of modules } \\
\text { and interpretations }\end{array}$ & 17 & 8.62 & 8 & 7.69 & 8.15 \\
\hline & $\begin{array}{l}\text { 2-1-5distinguishing \& } \\
\text { analyzing alternative } \\
\text { interpretations and modules }\end{array}$ & 12 & 6.09 & 1 & 0.96 & 3.52 \\
\hline & $\begin{array}{l}\text { 2-1-6comunicating and } \\
\text { defending scientific proofs }\end{array}$ & 3 & 1.52 & 00 & 00 & 0.76 \\
\hline Total & & 158 & 80.18 & 85 & 81.71 & 80.94 \\
\hline \multirow[t]{6}{*}{$\begin{array}{l}2-2 \quad \text { Understanding } \\
\text { scientific investigation }\end{array}$} & $\begin{array}{l}\text { 2-2-1 investigating how } \\
\text { system work }\end{array}$ & 8 & 4.06 & 3 & 2.88 & 3.47 \\
\hline & $\begin{array}{l}\text { 2-2-2 scientists conduct } \\
\text { research for many reasons, to } \\
\text { discover a scientific } \\
\text { phenomenon as an example }\end{array}$ & 5 & 2.53 & 2 & 1.92 & 2.22 \\
\hline & 2-2-3 using technology & 12 & 6.09 & 1 & 0.96 & 3.52 \\
\hline & $\begin{array}{l}\text { 2-2-4 using math in } \\
\text { scientific investigations }\end{array}$ & 6 & 3.04 & 1 & 8.65 & 5.84 \\
\hline & $\begin{array}{l}\text { 2-2-5 scientific } \\
\text { interpretations }\end{array}$ & 5 & 2.53 & 1 & 0.96 & 1.74 \\
\hline & $\begin{array}{l}\text { 2-2-6 results of science } \\
\text { investigation }\end{array}$ & 3 & 1.52 & 3 & 2.88 & 2.2 \\
\hline Total & & 39 & 19.77 & 19 & 18.25 & 19.01 \\
\hline $\begin{array}{l}\text { Total calculated on } \\
\text { standards }\end{array}$ & & 197 & 100 & 104 & 100 & 100 \\
\hline
\end{tabular}

As we see, the standard of 'the abilities needed for science survey' ranks first with a percentage of 80.99, whereas that of 'understanding scientific survey' ranks second with a percentage of 19.01. 
Table 5. Percentages of Sub Standards of Physics Sciences in the Eleventh and Twelfth Textbooks

\begin{tabular}{|c|c|c|c|c|c|c|}
\hline \multirow[t]{2}{*}{ physical sciences } & \multirow[t]{2}{*}{ elements of substandard } & \multicolumn{2}{|c|}{ Physics of $11^{\text {th }}$ grade } & \multicolumn{2}{|c|}{ Physics of $12^{\text {th }}$ grade } & \multirow[t]{2}{*}{ Total \% } \\
\hline & & $\begin{array}{l}\text { percentage } \\
\%\end{array}$ & frequency & $\begin{array}{l}\text { percentage } \\
\%\end{array}$ & frequency & \\
\hline \multirow[t]{4}{*}{ 3-1 structure of atom } & 3-1-1 structure of matter & 2.38 & 5 & 2.79 & 5 & 2.58 \\
\hline & 3-1-2 nucleus structure & 1.42 & 3 & 2.79 & 5 & 2.10 \\
\hline & 3-1-3 nuclear forces & 0.47 & 1 & 7.26 & 13 & 3.86 \\
\hline & 3-1-4 radioisotopes & 0.47 & 1 & 11.73 & 21 & 6.10 \\
\hline \multirow{7}{*}{$\begin{array}{l}\text { Total } \\
\text { 3-2 structure and properties of } \\
\text { matter }\end{array}$} & & 4.74 & 10 & 24.57 & 44 & 14.65 \\
\hline & $3-2-1$ interaction of atoms & 4.76 & 10 & 3.91 & 7 & 4.32 \\
\hline & 3-2-2 element structure & 1.42 & 3 & 0 & 0 & 0.71 \\
\hline & 3-2-3 atomic bonds & 6.66 & 14 & 0 & 0 & 3.33 \\
\hline & $\begin{array}{l}\text { 3-2-4 natural properties of } \\
\text { compounds }\end{array}$ & 3.33 & 7 & 0 & 0 & 1.66 \\
\hline & $\begin{array}{l}\text { 3-2-5 solid, liquid and gaseous } \\
\text { matters }\end{array}$ & 3.33 & 7 & 2.79 & 5 & 3.06 \\
\hline & 3-2-6 carbon bonding. & 1.9 & 4 & 0 & 0 & 0.95 \\
\hline \multirow{6}{*}{$\begin{array}{l}\text { Total } \\
\text { 3-3 chemical reactions }\end{array}$} & & 21.40 & 45 & 6.70 & 12 & 14.05 \\
\hline & 3-3-1 chemical reaction & 0 & 0 & 0 & 0 & 0 \\
\hline & $\begin{array}{l}\text { 3-3-2 chemical reaction and } \\
\text { energy }\end{array}$ & 0.47 & 1 & 1.67 & 3 & 1.07 \\
\hline & $\begin{array}{l}\text { 3-3-3chemical reaction and charge } \\
\text { transfer }\end{array}$ & 0.47 & 1 & 0.55 & 1 & 0.51 \\
\hline & 3-3-4 time of chemical reaction & 0 & 0 & 0 & 0 & 0 \\
\hline & $\begin{array}{l}\text { 3-3-5 catalysts in chemical } \\
\text { reaction. }\end{array}$ & 0 & 0 & 0.55 & 1 & 0.27 \\
\hline \multirow{6}{*}{$\begin{array}{l}\text { Total } \\
\text { 3-4 forces and motion }\end{array}$} & & 0.94 & 2 & 2.77 & 5 & 1.85 \\
\hline & 3-4-1 Newton laws & 19.04 & 40 & 20.67 & 37 & 19.85 \\
\hline & 3-4-2 gravitational laws & 1.42 & 3 & 0.55 & 1 & 0.98 \\
\hline & 3-4-3 electrical force & 8.09 & 17 & 0.55 & 1 & 4.32 \\
\hline & 3-4-4 electrical force and gravity & 2.38 & 5 & 0.55 & 1 & 1.46 \\
\hline & 3-4-5 electromagnetic waves. & 0 & 0 & 8.93 & 16 & 4.46 \\
\hline \multirow{5}{*}{$\begin{array}{l}\text { Total } \\
3-5 \text { conservation of energy and } \\
\text { perturbation }\end{array}$} & & 30.93 & 65 & 31.25 & 56 & 31.09 \\
\hline & 3-5-1 universe energy & 9.04 & 19 & 6.14 & 11 & 7.59 \\
\hline & 3-5-2 forms of mechanical energy. & 13.80 & 29 & 11.73 & 21 & 12.76 \\
\hline & 3-5-3 heat & 5.23 & 11 & 0 & 0 & 2.61 \\
\hline & 3-5-4 order of objects. & 0.47 & 1 & 0.55 & 1 & 0.51 \\
\hline \multirow{5}{*}{$\begin{array}{l}\text { Total } \\
3-6 \text { interaction of energy and } \\
\text { matter }\end{array}$} & & 28.54 & 60 & 18.42 & 33 & 23.48 \\
\hline & 3-6-1 waves and energy & 3.33 & 7 & 3.35 & 6 & 3.34 \\
\hline & 3-6-2 magnetic waves & 5.23 & 11 & 5.58 & 10 & 5.40 \\
\hline & 3-6-3 atom and energy. & 4.28 & 9 & 5.58 & 10 & 4.93 \\
\hline & 3-6-4 flow of electrons. & 0.47 & 1 & 1.67 & 3 & 1.07 \\
\hline \multicolumn{2}{|l|}{ Total } & 13.31 & 28 & 16.18 & 29 & 14.74 \\
\hline \multicolumn{2}{|l|}{ Total summation } & 100 & 210 & 100 & 179 & 100 \\
\hline
\end{tabular}

The table above indicates that the percentages of the sub standards of physics are in the following order: $31.09 \%$ for motions and forces; $23.48 \%$ for energy reservation and disorder increase; $14.74 \%$ for energy and substance interactions; $14.65 \%$ for atomic structure; and $1.85 \%$ chemical interactions. 
Table 6. Percentages of the Distribution of the Sub Standards of Science and Technology

\begin{tabular}{|c|c|c|c|c|c|c|}
\hline \multirow[t]{3}{*}{ Science and technology } & \multirow[t]{3}{*}{ Elements of substandard } & \multicolumn{2}{|c|}{ Physics of $11^{\text {th }}$ grade } & \multicolumn{2}{|c|}{ Physics of $12^{\text {th }}$ grade } & \multirow[t]{3}{*}{ Total\% } \\
\hline & & Percentage & frequency & Percentage & frequency & \\
\hline & & $\%$ & & $\%$ & & \\
\hline \multirow[t]{5}{*}{$\begin{array}{l}\text { 4-1 abilities need for } \\
\text { technological design }\end{array}$} & $\begin{array}{l}\text { 4-1-1 identifying problems and } \\
\text { improving technological designs }\end{array}$ & 11.9 & 5 & 24.13 & 7 & 18.01 \\
\hline & $\begin{array}{l}\text { 4-1-2 suggesting designs and } \\
\text { choosing from alternative solutions }\end{array}$ & 11.9 & 5 & 6.89 & 2 & 9.39 \\
\hline & 4-1-3 applying the solution & 2.38 & 1 & 0 & 0 & 1.19 \\
\hline & $\begin{array}{l}4-1-4 \text { assessing the solution and its } \\
\text { results }\end{array}$ & 2.38 & 1 & 3.44 & 1 & 2.91 \\
\hline & $\begin{array}{l}4-1-5 \text { explaining and communicating } \\
\text { the problem }\end{array}$ & 0 & 0 & 0 & 0 & 0 \\
\hline Total & & 28.56 & 12 & 34.46 & 10 & 31.51 \\
\hline \multirow[t]{5}{*}{$\begin{array}{l}\text { 4-2-understanding science } \\
\text { and technology }\end{array}$} & $\begin{array}{l}\text { 4-2-1 methods of science and } \\
\text { technological research }\end{array}$ & 9.52 & 4 & 10.34 & 3 & 9.93 \\
\hline & $\begin{array}{l}\text { 4-2-2 scientific advanced and } \\
\text { technology }\end{array}$ & 38.09 & 16 & 34.48 & 10 & 36.28 \\
\hline & $\begin{array}{l}\text { 4-2-3 role of creativity and } \\
\text { imagination science and technology }\end{array}$ & 4.76 & 2 & 6.89 & 2 & 5.82 \\
\hline & $\begin{array}{l}\text { 4-2-4 motivations for investigation } \\
\text { and technological design }\end{array}$ & 16.66 & 7 & 13.79 & 4 & 15.22 \\
\hline & $\begin{array}{l}\text { 4-2-5 spreading technological } \\
\text { knowledge. }\end{array}$ & 2.38 & 1 & 0 & 0 & 1.19 \\
\hline Total & & 71.43 & 30 & 65.50 & 19 & 68.44 \\
\hline Total summation & & 100 & 42 & 100 & 29 & 100 \\
\hline
\end{tabular}

Table 6 above shows that the substandard of understanding science and technology ranks first, with a percentage of 68, followed by the sub standard of abilities needed for technological design with a percentage of 31.51.

Table 7. Percentages Calculated on the Sub Standards of Science from Personal and Societal Perspectives

\begin{tabular}{|c|c|c|c|c|c|c|}
\hline \multirow{2}{*}{$\begin{array}{l}\text { Science from personal and } \\
\text { social perspectives }\end{array}$} & \multirow[t]{2}{*}{ element of substandard } & \multicolumn{2}{|c|}{ Physics of $11^{\text {th }}$ grade } & \multicolumn{2}{|c|}{ Physics of $12^{\text {th }}$ grade } & \multirow[t]{2}{*}{ Total \% } \\
\hline & & $\begin{array}{l}\text { Percentage } \\
\%\end{array}$ & frequency & $\begin{array}{l}\text { Percentage } \\
\%\end{array}$ & frequency & \\
\hline \multirow[t]{7}{*}{ 5-1 individual and public health } & $\begin{array}{l}\text { 5-1-1ways and risks of } \\
\text { limitation }\end{array}$ & 31.81 & 7 & 5 & 1 & 18.40 \\
\hline & $\begin{array}{l}\text { 5-1-2disease prevention and } \\
\text { cure }\end{array}$ & 0 & 0 & 5 & 1 & 2.5 \\
\hline & 5-1-3personal choice. & 4.54 & 1 & 0 & 0 & 2.27 \\
\hline & $\begin{array}{l}\text { 5-1-4 personal mood and } \\
\text { behavior }\end{array}$ & 4.54 & 1 & 0 & 0 & 2.27 \\
\hline & $\begin{array}{l}\text { 5-1-5 food choice and } \\
\text { preparation }\end{array}$ & 0 & 0 & 0 & 0 & 0 \\
\hline & $\begin{array}{l}\text { 5-1-6 families and basic health } \\
\text { needs }\end{array}$ & 0 & 0 & 0 & 0 & 0 \\
\hline & 5-1-7sex relations. & 0 & 0 & 0 & 0 & 0 \\
\hline Total & & 40.89 & 9 & 5 & 2 & 22.94 \\
\hline
\end{tabular}




\begin{tabular}{|c|c|c|c|c|c|c|}
\hline \multirow[t]{3}{*}{ 5-2 population growth } & $\begin{array}{l}\text { 5-2-1factors affecting } \\
\text { population growth }\end{array}$ & 0 & 0 & 0 & 0 & 0 \\
\hline & $\begin{array}{l}\text { 5-2-2factors affecting rate of } \\
\text { births and fertility }\end{array}$ & 0 & 0 & 0 & 0 & 0 \\
\hline & 5-2-3 family support & 0 & 0 & 0 & 0 & 0 \\
\hline Total & & 0 & 0 & 0 & 0 & 0 \\
\hline \multirow[t]{3}{*}{ 5-3 natural resources } & 5-3-natural resources & 4.54 & 1 & 10 & 2 & 7.27 \\
\hline & 5-3-2limited natural resources & 4.54 & 1 & 0 & 0 & 2.27 \\
\hline & 5-3-3 applied natural systems. & 4.54 & 1 & 20 & 4 & 2.27 \\
\hline Total & & 13.62 & 3 & 30 & 6 & 21.81 \\
\hline \multirow[t]{3}{*}{ 5-4 quality of environment } & 5-4-1 economic systems & 0 & 0 & 5 & 1 & 2.5 \\
\hline & $\begin{array}{l}\text { 5-4-2 human influences on } \\
\text {.natural and chemical courses }\end{array}$ & 0 & 0 & 5 & 1 & 2.5 \\
\hline & $\begin{array}{l}\text { 5-4-3 factors affecting quality } \\
\text { of environment. }\end{array}$ & 0 & 0 & 0 & 0 & 0 \\
\hline Total & & 0 & 0 & 10 & 2 & 5 \\
\hline \multirow[t]{4}{*}{ 5-5 natural and human risks } & $\begin{array}{l}\text { 5-5-1natural modification of } \\
\text { earth }\end{array}$ & 4.54 & 1 & 5 & 1 & 4.77 \\
\hline & $\begin{array}{l}\text { 5-5-2human activities and } \\
\text { natural risks }\end{array}$ & 0 & 0 & 0 & 0 & 0 \\
\hline & 5-5-3 nature of Risks & 4.54 & 1 & 20 & 4 & \\
\hline & 5-5-4 natural and human risks & 4.54 & 1 & 0 & 0 & \\
\hline Total & & 13.62 & 3 & 25 & 5 & \\
\hline $\begin{array}{l}5-6 \text { science and technology in the } \\
\text { context of local, regional, and }\end{array}$ & $\begin{array}{l}\text { 5-6-1 the relation between } \\
\text { science and technology }\end{array}$ & 4.54 & 1 & 0 & 0 & \\
\hline \multirow[t]{4}{*}{ international challenges } & $\begin{array}{l}5-6-2 \text { the need for } \\
\text { understanding the fundamental } \\
\text { concepts of science and } \\
\text { technology }\end{array}$ & 4.54 & 1 & 5 & 1 & \\
\hline & $\begin{array}{l}\text { 5-6-3 challenges facing } \\
\text { scientific and technological } \\
\text { advances }\end{array}$ & 9.09 & 2 & 10 & 2 & \\
\hline & $\begin{array}{l}\text { 5-6-4proposals for new } \\
\text { research and technologies. }\end{array}$ & 4.54 & 1 & 0 & 0 & \\
\hline & $\begin{array}{l}\text { 5-6-5 human activities and the } \\
\text { life of other creatures. }\end{array}$ & 9.09 & 2 & 10 & 2 & \\
\hline Total & & 31.8 & 7 & 25 & 5 & \\
\hline Total summation & & 100 & 22 & 100 & 20 & \\
\hline
\end{tabular}

As we notice in table 7 above, the descending order of the percentages of the sub standards of 'science from personal and societal perspectives' is as follows:

$28.40 \%$ for 'the role science and technology in local, national, and global challenges'; $22.94 \%$ for 'personal and public health'; 21.81 for 'natural resources', 19.31 for 'natural and human risks'; and 5 for 'clean environment'. The curriculum lacks the substandard of rise of population. 
Table 8. Percentages Calculated on the Sub Standards of History and Nature of Science

\begin{tabular}{|c|c|c|c|c|c|c|}
\hline \multirow{2}{*}{$\begin{array}{l}\text { History and nature } \\
\text { science }\end{array}$} & \multirow[t]{2}{*}{ Elements of sub standards } & \multicolumn{2}{|c|}{ Physics of $11^{\text {th }}$ grade } & \multicolumn{2}{|c|}{ Physics of $12^{\text {th }}$ grade } & \multirow{2}{*}{$\begin{array}{l}\text { Total } \\
\%\end{array}$} \\
\hline & & $\begin{array}{l}\text { percentage } \\
\%\end{array}$ & frequency & $\begin{array}{l}\text { percentage } \\
\%\end{array}$ & frequency & \\
\hline \multirow[t]{5}{*}{ 6-1 science as human effort } & 6-1-1science & 21.43 & 6 & 11.11 & 4 & 16.27 \\
\hline & individual or team effort & & & & & \\
\hline & 6-1-2 scientists ethics. & 0 & 0 & 22.22 & 8 & 11.11 \\
\hline & 6-1-3scientists & 0 & 0 & 2.77 & 1 & 1.38 \\
\hline & backgrounds. & & & & & \\
\hline total & & 21.43 & 6 & 36.10 & 13 & 28.76 \\
\hline \multirow{5}{*}{$\begin{array}{l}\text { 6-2nature of scientific } \\
\text { knowledge }\end{array}$} & 6-2-1science & 7.14 & 2 & 8.33 & 3 & 7.73 \\
\hline & characteristics & & & & & \\
\hline & scientific & 10.71 & 3 & 11.11 & 4 & 10.91 \\
\hline & interpretation. & & & & & \\
\hline & $\begin{array}{l}6-2 \text {-3science knowledge is } \\
\text { subjected to change. }\end{array}$ & 3.57 & 1 & 2.78 & 1 & 3.17 \\
\hline total & & 21.42 & 6 & 22.22 & 8 & 21.82 \\
\hline \multirow[t]{5}{*}{$\begin{array}{l}\text { 6-3science from historical } \\
\text { perspective }\end{array}$} & $\begin{array}{l}\text { 6-3-1 advancement of } \\
\text { scientific and }\end{array}$ & 10.71 & 3 & 8.33 & 3 & 9.25 \\
\hline & technological knowledge & & & & & \\
\hline & $\begin{array}{l}\text { 6-3-2change of scientific } \\
\text { knowledge. }\end{array}$ & 17.85 & 5 & 11.11 & 4 & 14.48 \\
\hline & $\begin{array}{l}\text { 6-3-3influence of science } \\
\text { and technology on society }\end{array}$ & 21.42 & 6 & 13.89 & 5 & 17.65 \\
\hline & $\begin{array}{l}\text { 6-3-4 nature of scientific } \\
\text { knowledge. }\end{array}$ & 7.14 & 2 & 8.33 & 3 & 7.73 \\
\hline total & & 57.12 & 16 & 41.66 & 15 & 49.39 \\
\hline Total summation & & 100 & 28 & 100 & 36 & 100 \\
\hline
\end{tabular}

The table above shows that the calculated percentages on the sub standards of history and science are 49.39 for 'the historical perspective of science', 28.75 for 'science as a human effort', and 21.82 for 'the nature of scientific knowledge'.

Table (9) below presents the results for the frequencies and percentages calculated on each of the content standards in the physics curriculum of the two grades.

Table 9. Percentages of Content Standards

\begin{tabular}{|c|c|c|c|c|c|c|c|}
\hline \multirow[t]{2}{*}{ standard } & \multicolumn{2}{|l|}{$11^{\text {th }}$ grade } & \multicolumn{2}{|l|}{$12^{\text {th }}$ grade } & \multicolumn{2}{|l|}{ Total } & \multirow{2}{*}{$\begin{array}{c}\text { criteria } \\
\text { percentage }\end{array}$} \\
\hline & percentage $\%$ & frequency & $\%$ percentage & frequency & percentage $\%$ & frequency & \\
\hline 1. Unified concepts and processes & 26.61 & 181 & 17.11 & 76 & 21.86 & 257 & 10 \\
\hline 2. Science as an investigation & 28.97 & 197 & 23.42 & 104 & 26.19 & 301 & 20 \\
\hline 3. Physical sciences & 30.88 & 210 & 40.31 & 179 & 35.59 & 389 & 30 \\
\hline 4. Science \&technology & 6.17 & 42 & 6.53 & 29 & 6.35 & 71 & 15 \\
\hline $\begin{array}{l}\text { 5. Science from personal and } \\
\text { social perspectives }\end{array}$ & 3.23 & 22 & 4.50 & 20 & 3.86 & 42 & 15 \\
\hline \multirow[t]{2}{*}{ 6. History \&nature of science } & 4.11 & 28 & 8.11 & 36 & 6.11 & 64 & 10 \\
\hline & 100 & 680 & 100 & 444 & 100 & 1124 & 100 \\
\hline
\end{tabular}

As we notice, the standard of 'physical sciences' come in the first place with a percentage of 35.59; 'science as a survey' comes second with a percentage of 26.19; 'the unified concepts and processes' comes third with a percentage of 21.86; 'science and technology' comes fourth with a percentage of 6.35; 'science from personal and societal perspectives' comes fifth; and the standard of 'history and nature of science'comes in the sixth place with a percentage of 6.11 . 
Besides, the table above shows that the percentages of the six standards do not match the expected percentages. The rate of differences reaches $13 \%$, as in the standard of unified concepts and processes of science. While some of the percentages exceed the expected percentages for the standards of 'unified concepts and processes', 'science as a survey', and 'physical sciences', other percentages are below the expected rates, as those of 'science and technology', 'science from personal and societal perspectives', and history and nature of science'.

The low rates of the standards of science as a survey and that of unified concepts and processes can be attributed to the rise in the rate of the scientific content of the physics of the twelfth grade, which reaches $40.32 \%$. This rate exceeds that of the eleventh grade, which is $30.8 \%$. This result indicates that the excessive interest in including scientific knowledge in the curriculum negatively influences the interest in including the humanistic dimensions of 'the history and nature of science' and its relation to technology, which was stressed by AAAS.

Also, this can be attributed to the nature of the content of the subjects covered in both textbooks, which requires survey and research. Further, the intensity of scientific material and the shortage of time led to cutting down the number of the activities included in the curriculum.

The rates of including the standard of 'science and technology' in both textbooks were the same, though below expectations. This might be attributed to the fact that this criterion is still a new one. The concentration of this standard on understanding science and technology was more than on the abilities needed for technological design. This result might also be attributed to the fact that syllabus designers did not have a clear vision as to the importance of scientific technology.

The concentration of the standard of 'science from personal and societal perspectives' was on the substandard of 'the role of science and technology in addressing local, national, and international challenges', followed by the substandard of 'individual and public health' and the substandard of 'natural resources' respectively. This indicates that syllabus designers were concerned of showing the importance of science to the individual and the community. We can figure out this from the following percentages calculated on the standard of 'science for the community and the role of man': 19\% for the substandard of 'the different risks and challenges encountering people' and 'the role of man in minimizing these'; $11.9 \%$ for the substandard of 'man employs various natural resources as systems'; and 9.52\% for the substandard 'scientific and technological advances are influenced by the social challenges and problems'. The results pertaining to this standard indicate that some of its indicators disappeared from the physics curriculum of the secondary stage, as selecting the type of food, family basic health needs, gender relations and human progress, population growth, etc. The factor behind this result could be the omission of certain subjects that contradicted the Arab Muslim context.

As for the standard of 'history and nature of science', the percentage calculated was more in the physics of the twelfth grade than in that of the eleventh grade. Some indicators of this standard were not included in the textbook of the eleventh grade, as the sub standards of 'scientists enjoy ethical traits' and 'scientists are influenced by social, cultural, and personal beliefs'. This can be explained based on the fact thatthe curriculum designers, who included information on the atom and its nature and the relevant scientists' contributions, were not aware of this aspect of science and therefore were concerned of preserving the traditional structure of the textbook, which focuses on content.

Concerning the historical perspective, the historical background pertaining to the invention of electricity and its influence contributed to the high percentage of this standard in the physics of the eleventh grade.

The findingsof the presentstudy match those of Kesidou and Roseman (2002), Safi (2005), Canaan (2005) and Al-Atrash (2006). Based on this, we can conclude that the physics of the secondary of Palestinian schools observe, in some areas, the content standards enlisted under the international standards of science education, yet other areas need improvement so as to upgrade the students' level of science literacy and achievement.

\section{Recommendations}

In view of the results, the researcher recommends the following:

-Physics teachers training programs should consider content standards in order to enable teachers to better understand them.

-National researchers should expand and enhance research on science pedagogy though conducting studies that address other standards of science education, including teaching methods, career development, science education programs, science education systems, and educational assessment. 


\section{References}

Abu Masmah, R. (2006). An Analytical Study of the Questions included in Physics Textbooks of the SecondaryStage and General Exams in Light of Modern International standards. Unpublished MA Thesis. Amman Arab University for Higher Studies, Amman, Jordan.

Al-Khalidi, M. (2004). Science Literacy in Palestinian New Palestinian Science Curricula: An Analytical Critical Study. Al-Qattan Center for Education Research and Development, Ramallah, Palestine.

Al-Khattaybeh, A., \& Al-Shu'ali A. (2007). Observing American National Standards of science Content by the Science Textbook of the Fifth Grade in Jordan. Al-Sharjah University Magazine for Legislative and Human Studies, 4(1), 173-198.

Allulu, F. (2007). Quality Level of Physics Subjects in Science Primary Stage Textbooks in light of International Standards. American Association for the Advancement of Science (1989). Project 2061-Science for AllAmericans.Washington DC: AAAS.

Badran, A. (1991). Science Curricula in Gulf Countries and correspondence with the Requirements of Scientific and Cultural Development. Gulf Countries Education Office, Al-Riyadh, Saudi Arabia.

Canaan, Khalid. (2005). Assessment of the Reality of Science Education at Grades Five to Eight in Jordan in Light of American National Standards. Unpublished Doctorate Dissertation. Amman Arab University for Higher Studies, Amman, Jordan.

Cavallo, L., Rozman, M., \& Potter, H. (2004). GenderDifferences in Learning Constructs, Shifts in Learning Constructs, And Their Relationship To Course Achievement In A StructuredInquiry, Yearlong College Physics Course For Life Science Majors. School Science and Mathematics, 104(66), 288-301. https://doi.org/10.1111/j.1949-8594.2004.tb18000.x

Chiappeta, F., \& Sethna, G. (1991). A Method to quantify major Themes of Scientific Literacy in Science Textbooks. Journal of Research in Science Teaching, 28(8), 713-725. https://doi.org/10.1002/tea.3660280808

Chiappetta, F., \& Sethna, G. (1993). Do middle School Life Science Textbooks provide a balance of Scientific Literacy Themes? Journal of Research in Science Teaching, 30(7), 787-797. https://doi.org/10.1002/tea.3660300714

Goodrum, G., Hackling, M., \& Rennie, L. (2001). The Status and Quality of Teaching and Learning of Science in Australian Schools, A Research Report Prepared for the Department ofEducation, Training and Youth Affairs. Retrieved June 10/2009 from http://www.dest.gov.au/schools/Publications/2001/Science/chap 2.Htm

Hampton, E., \& Licona, M. (2001). An merging Understanding of Science Literacy: MovingToward a Curriculum of Inclusion", Univ. of Texas at El Paso. Retrieved Feb 9/ 2009 from http://www.sjsu.edu/elementaryed/ejlts/archives/diversity/hampton.pdf

Haury, D. L. (2000). High School Biology Textbooks, Do Not Meet National Standards, "ERIC Clearinghouse for Science Mathematics and Environmental Education, Columbus OH. ERIC Digest. (On- line). ERIC document reproductions service no. Ed 463949. Retrieved from http://www.ericfacility.net/ericdigests/ed463949html

National Academy of Sciences (1996). National Science Education Standards Second Printing USA. National Academy Press.

National Academy of Sciences (NAS) (1995). National Science Education Standards. Retrieved Feb 15/ 2009 from http://www.nap.edu/redingroom/books/nses/html/overview.html

National Research Council (1995). National Science Education Standards. Washington, DC., National Academy Press.

National Research Council (1996). National Science Education Standards. Washington, DC: National Academy Press (on-line). Retrieved Dec 25/ 2008 from www.nap.edu/readingroom/books/nses/html

National Research Council (NRC) (1994). National Science Education Standards Draft. Washington, DC: National Academy Press.

Safi, A. (2005). The Impact of Teaching International Science Education Standardized Content on the Level of Science literacy of Secondary Stage Student. Unpublished Doctorate Dissertation. Amman Arab University for Higher Studies, Amman, Jordan.

Skeik, H. (2006). What Is Physics. Retrieved from www.hazemsakeek.com/physics-lectures/whatis physics.html 
Trowbridge, W., Bybee, W., \& Powell, C. (2000). Teaching Secondary School Science-Strategies for Developing Scientific Literacy (7th ed.). New Jersey, Prentice-Hall, Inc., Pearson Education.

Westerlund, F., \& West, S. (2001). The Use of the National Science Education Standards to Critique a Standardized High School Biology Examination. Electronic Journal of Science Education- EJSE, (on-line), 6(2). 